\title{
DIE ONTWIKKELING EN INHOUD VAN 'N MAATSKAPLIKE GROEPWERK-BEMAGTIGINGSPROGRAM VIR ALKOHOLAFHANKLIKE BEJAARDES
}

\section{LS Geyer \& H Strydom}

\section{INLEIDING}

In hierdie artikel word gefokus op 'n maatskaplike groepwerk-bemagtigingsprogram, ooreenkomstig 'n sterkteperspektief, wat ontwikkel en aangebied is vir alkoholafhanklike bejaardes verbonde aan 'n geregistreerde behandelingsentrum. Die voorgenoemde program is deur die navorsers ontwikkel, gemik op die eiesoortige behoeftes, sterktes en uitdagings van dié kliëntegroep.

Die doelwitte van hierdie artikel is (a) om die proses waarvolgens 'n maatskaplike groepwerkbemagtigingsprogram vir alkoholafhanklike bejaardes ontwikkel en aangebied is, te bespreek, asook (b) om die programinhoud kortliks weer te gee, sodat maatskaplikewerk-praktisyns die program enersyds kan benut, en andersyds gestimuleer word tot soortgelyke praktykinisiatiewe.

\section{AGTERGROND/PROBLEEMSTELLING}

Wêreldwyd verhoog die lewensverwagting van die mensdom, insluitend bejaardes, vanweë die ontwikkeling van die mediese wetenskap. Terselfdertyd berig Brümmer (2004:23) dat alkoholafhanklikheid onder Suid-Afrikaners toeneem. In sekere provinsies van Suid-Afrika, onder andere Gauteng, kom alkoholafhanklikheid so hoog as ses uit elke tien mense voor. Parry, Pluddemann, Steyn, Bradshaw, Norman \& Laubscher (2005) het in 'n Suid-Afrikaanse studie bevind dat $27,6 \%$ mans en $9,6 \%$ vroue ouer as 55 jaar van alkohol afhanklik is. Hierdie toestand noodsaak dringende ingrype van professies, soos Maatskaplike Werk, ten einde geskikte behandelingsprogramme vir dié ouderdomsgroep te ontwikkel en te toets (Barnea \& Teichman, 1994:133; Gurnack \& Thomas, 1989:652; O'Connell, Chin, Cunningham \& Lawlor, 2003:664; Ticehurst, 1990:252; Widner \& Zeichner, 1991:15).

Cox (2001:305) is van mening dat die sterkteperspektief geskik is vir maatskaplikewerk-dienslewering aan diverse bevolkingsgroepe wat dikwels as magtelose groeperinge geklassifiseer word. Volgens hierdie standpunt blyk dit dat Suid-Afrika, met uiteenlopende kliëntegroepe, 'n ideale geleentheid bied vir die toepassing van die sterkteperspektief. Die bejaarde bevolking in Suid-Afrika is eweneens deel van hierdie diverse kliëntegroepe.

Ondanks menings dat maatskaplikewerk-dienslewering aan die alkoholafhanklike bejaarde onnodig is weens swak prognose (Giordano \& Beckham, 1985:79; Ticehurst, 1990:258), meen Perkins en Tice (1999:181) daarteenoor dat bejaardes dikwels 'n beter prognose as hul jonger eweknieë toon. Argumente dat bejaardes 'n swak of geen prognose toon, is te wyte aan die feit dat die alkoholafhanklike bejaarde dikwels reeds gedurende volwassenheid alkoholafhanklikheid ontwikkel het en dit steeds nie oorwin het nie. Gevolglik word stereotipe beelde, soos dronkaard, aan die alkoholafhanklike bejaarde toegedig.

Behandelingsprogramme wat tans in Suid-Afrika by verskeie behandelingsentra, statutêr en vrywillig, benut word, is ontwerp vir maatskaplikewerk-dienslewering gerig op alle ouderdomsgroepe (Geyer, 2003:214). Hierdie behandelingsprogramme is dikwels, weens die unieke behoeftes en uitdagings van die bejaarde, nie tot hul voordeel nie. Outeurs, soos Deblinger (2000:82), Dunne (1994:609), Giordano en Beckham (1985:66), Gurnack en Hoffman 
(1992:878), Perkins en Tice (1999:181) asook Widner en Zeichner (1991:13), meen dat alkoholafhanklike bejaardes aan 'n uniek-ontwerpte behandelingsprogram onderwerp moet word. Vanuit die voorafgaande blyk dit dat daar 'n behoefte bestaan om afsonderlike behandelingsprogramme vir die alkoholafhanklike bejaarde te ontwikkel en te toets wat op hulle eiesoortige omstandighede, behoeftes en sterktes gemik is.

Maatskaplike Werk beskik oor drie primêre metodes van dienslewering, waaronder maatskaplike groepwerk. Barrie (1990:155-157) wys op verskeie voordele wat maatskaplike groepwerk vir die alkoholis inhou. Beaver en Miller (1992:70) meen voorts dat maatskaplike groepwerk uitdagend, stimulerend en belonend vir die bejaarde is. Voorts bestaan daar 'n verskeidenheid praktykteorieë en -modelle wat benut kan word in dienslewering aan die alkoholis. Dit geld ook vir die alkoholafhanklike bejaarde. Die sterkteperspektief fokus op die holistiese persoon binne sy omgewing. Hierdie benadering kan die bejaarde persoon help om soveel as moontlik kontrole oor sy lewe te behou. Die sterktes waartoe die bejaarde nog steeds in staat is, ondanks sy gevorderde leeftyd, kan uitgebou word (Fast \& Chapin, 2002:145). Hiervolgens blyk dit dat die toepassingsmoontlikhede van maatskaplike groepwerk in dienslewering aan die alkoholafhanklike bejaarde, vanuit 'n sterkteperspektief, ondersoek moet word.

Vanuit 'n omvattende literatuurstudie blyk dit dat navorsing rondom die toepassingsmoontlikhede van die sterkteperspektief ten opsigte van alkoholafhanklike bejaardes ontbreek. Graybeal (2001:241) sluit hierby aan deurdat hy daarop wys dat etlike diensvelde nog bestudeer moet word ten opsigte van dienslewering ooreenkomstig die sterkteperspektief. Parry et al. (2005) skets die Suid-Afrikaanse situasie ten opsigte van alkoholafhanklikheid soos volg:

"In South Africa (and many developing countries) there is currently a dearth of treatment and other interventions for reducing risky drinking in general and particularly in areas situated away from urban centers."

Gevolglik het die navorsingsvraag ontstaan: "Watter programaktiwiteite vanuit die literatuur en empiriese navorsings moet ingesluit word in 'n maatskaplike groepwerk-bemagtigingsprogram ten einde alkoholafhanklike bejaardes deur middel van 'n sterkteperspektief te bemagtig?" Terselfdertyd is 'n leemte aan sodanige program geïdentifiseer en het die navorsers besluit om 'n maatskaplike groepwerk-bemagtigingsprogram vir alkoholafhanklike bejaardes in Suid-Afrika te ontwerp.

\section{NAVORSINGSMETODOLOGIE}

'n Toegepaste ondersoek, spesifiek volgens die variant intervensienavorsing (Fouché \& De Vos, 2005:109), is benut ten einde 'n nuwe program (tegnologie) te ontwikkel. Volgens 'n verkennende navorsingsontwerp is "wat?" vrae onderneem ten einde die probleem te ondersoek (Babbie, 2004:97-89; Fouché \& De Vos, 2005:106). Hierdie navorsingsontwerp het die navorsers in staat gestel om 'n akkurate profiel van alkoholafhanklike bejaardes, asook hul behoeftes, sterktes en uitdagings saam te stel. Hierdie data is eventueel sinvol in 'n groepwerkbemagtigingsprogram geïnkorporeer sodat die program spesifiek op die alkoholafhanklike bejaarde afgestem is. Ontwikkelings- en benuttingsnavorsing (DR \& U-model) is as die oorkoepelende navorsingsmodel gebruik. Vervolgens word die verskillende fases van hierdie model bespreek, terwyl die navorsingsmetodologie by elke fase van die navorsingsproses duideliker omskryf sal word. Voorts word die proses van programontwikkeling, die programinhoud, en programresultate by die toepaslike fases bespreek. 


\section{ONTWIKKELINGS- EN BENUTTINGSNAVORSING (DR \& U-MODEL)}

\section{Fase 1: Analise}

Analise behels onder meer die identifisering van 'n probleem en die beskouing van bestaande maatskaplike tegnologie (bv. groepwerkinisiatiewe). Hierdie fase is onderneem deur middel van 'n omvattende literatuurstudie ten opsigte van alkoholisme, bejaardheid, maatskaplike groepwerk en die sterkteperspektief. Vanuit dié studie is daar bevind dat kliënte, soos alkoholafhanklike bejaardes, bemagtig kan word volgens 'n sterkteperspektief (Norman, 2000:2-3). Dieselfde outeur, asook Kirst-Ashman (2003:52-53) kom in hul handboeke tot die bevinding dat die sterkteperspektief nie oor 'n eiesoortige hulpverleningsproses beskik nie, maar wel binne 'n bemagtigingsproses geakkommodeer word. Alvorens 'n nuwe groepwerk-bemagtigingsprogram ontwikkel is, het die navorsers bestaande groepwerkinisiatiewe ondersoek.

\section{- Bestaande groepwerkinisiatiewe}

Die analise fase is voortgesit deur middel van 'n empiriese ondersoek. 'n Opnameprosedure is met $27(\mathrm{~N}=27)$ maatskaplikewerk-praktisyns, verbonde aan geregistreerde behandelingsentra in Suid-Afrika, onderneem ten einde die aard en omvang van bestaande groepwerkinisiatiewe vir alkoholafhanklike bejaardes te verken. Data-insameling is onderneem deur gestruktureerde onderhoude aan die hand van 'n onderhoudskedule. Dié onderhoudskedule het oop, meervoudige keuse en geskaleerde vrae (Strydom, 2000:124-131), asook geslote vrae bevat ten einde kwantitatiewe en kwalitatiewe data te versamel. Vir die doeleindes van data-ontleding is dieselfde prosedure gevolg as wat hieronder by die bejaarde deelnemers bespreek word.

Die maatskaplikewerk-deelnemers is deur middel van ' $\mathrm{n}$ beskikbaarheidsteekproef, as niewaarskynlikheidseleksie-tipe steekproef, by die ondersoek betrek (Babbie, 2004:183-184). Slegs dié praktisyns wat hul vrywillig tot die ondersoek verbind het, is by die onderhoude betrek. Daar is bevind dat maatskaplike werkers die volgende temas tydens groepwerkbyeenkomste onderneem oor 'n gemiddelde tydperk van drie weke (sien Skematiese Voorstelling 1):

SKEMATIESE VOORSTELLING 1

TEMAS VAN GROEPWERKSESSIES BY ENKELE GEREGISTREERDE BEHANDELINGSENTRA IN SUID-AFRIKA

\begin{tabular}{|c|c|}
\hline Week van behandeling & Temas ingesluit by groepwerkbyeenkomste \\
\hline Week 1 & $\begin{array}{l}-\quad \text { Oorsake en gevolge van alkoholafhanklikheid. } \\
\text { - Kliënte word gelei tot die erkenning en aanvaarding dat } \\
\text { hy/sy van alkohol afhanklik is. } \\
\text { - Ontwikkeling van 'n vertrouensverhouding in die groep. }\end{array}$ \\
\hline Week 2 & $\begin{array}{l}\text { - } \text { Die hantering van verlies. } \\
\text { - } \text { Godsdiensbeoefening. } \\
\text { - } \text { Kontering van emosies. } \\
\text { - Konflikhantering. } \\
\text { - MIV/Vigs: kennis van die toestand asook die voorkoming } \\
\text { daarvan. } \\
\text { - } \text { Probleemoplossing. } \\
\text { - Streshantering. } \\
\text { - Tydsbestuur: hoe om jou tyd effektief te bestuur. } \\
\text { - Reoefening van stokperdjies. } \\
\text { Rasionele denkpatrone: hoe om rasioneel te dink. }\end{array}$ \\
\hline
\end{tabular}




\begin{tabular}{|c|c|}
\hline Week 3 & $\begin{array}{l}\text { - Toekomsbeplanning: die opstel van die sogenaamde } \\
\text { "nugterheidsplan." } \\
\text { - Begelei kliënte tot die heropbou en versterking van } \\
\text { verhoudings met betekenisvolle andere. } \\
\text { - Fasilitering van suksesvolle toetrede tot die huwelikslewe } \\
\text { deur die eggenote te betrek by groepwerksessies. } \\
\text { - Nasorgdienste: die aard en noodsaaklikheid daarvan vir } \\
\text { elke gerehabiliteerde alkoholis. }\end{array}$ \\
\hline
\end{tabular}

Vanuit Skematiese Voorstelling 1 kan die volgende afleidings gemaak word:

- Week 1 is daarop gerig om die alkoholafhanklike persoon te lei tot die erkenning van sy/haar drankprobleem. Daarbenewens word die groeplede gelei tot die aanvaarding van hul uitdagings soos om hom/haar van alkohol te weerhou. Groeplede word ook gemotiveer om moontlike uitdagings op 'n konstruktiewe wyse te hanteer.

- Gedurende die tweede week word verskeie onderwerpe wat vir die alkoholafhanklike persoon van belang mag wees, soos konflikhantering, bespreek. Hierdie onderwerpe is enersyds daarop gerig om die kliënt van noodsaaklike kennis te voorsien oor alkoholverwante probleme, en andersyds om lewensvaardighede vir die groeplede te leer wat hul maatskaplike funksionering kan verbeter deur byvoorbeeld alkoholinname te staak.

- Week 3 is daarop gerig om die alkoholafhanklike persoon voor te berei op herinskakeling in die huwelik, gesin en gemeenskap. Dit blyk asof hierdie voorbereiding veral daarop fokus om suksesvolle toetrede sonder enige betrokkenheid by alkoholinname, te bevorder.

- Voorts omsluit die behandeling gedurende die derde week 'n faset waartydens die kliëntsisteem georiënteer word ten opsigte van nasorgdienste, soos hoe om daarvan gebruik te maak.

- Volgens die onderwerpe wat tydens groepbyeenkomste hanteer word, blyk dit duidelik dat 'n holistiese benadering gevolg word. Fisiese, psigiese, sosiale en spirituele behoeftes van die alkoholafhanklike persoon geniet aandag.

Afgesien van die maatskaplikewerk-deelnemers se insette is alkoholafhanklike bejaardes se unieke omstandighede eweneens ondersoek ten einde hul behoeftes, uitdagings en sterktes te identifiseer.

\section{- Profiel van alkoholafhanklike bejaardes}

Die spesifieke behoeftes, uitdagings en sterktes van alkoholafhanklike bejaardes is verken deur 'n omvattende bio-psigososiale en demografiese profiel saam te stel. Verskillende eienskappe van die bejaarde deelnemers is verken soos geslag, ouderdom, huwelikslewe, verhouding met naasbestaandes, vryetydsbesteding, rolverandering, godsdienstige en geestelike lewe, asook opvoedkundige kwalifikasies, aard van werk óf aftrede, finansiële posisie en behuising.

'n Opnameprosedure is met $56(\mathrm{~N}=56)$ bejaarde deelnemers van 58 jaar en ouer onderneem ten einde die voorgenoemde profiel saam te stel. Data-insameling is onderneem deur gestruktureerde onderhoude aan die hand van 'n onderhoudskedule. Dié onderhouskedule het oop, meervoudige keuse en geskaleerde vrae (Strydom, 2000:124-131), asook geslote vrae bevat ten einde kwantitatiewe en kwalitatiewe data te versamel. Kwantitatiewe data is deur 'n statistiese konsultasiediens verwerk deur middel van die statistiese rekenaarpakket, SAS System 
for Windows (SAS Institute Inc., 2002-2005). Kwalitatiewe data is ontleed deur sentrale temas en bepaalde tendense sistematies te ontleed, te kategoriseer en die frekwensie daarvan te bepaal. Die eenhede van ontleding is deeglik vooraf beplan sodat 'n doelgerigte ontleding van die data verseker is (Strydom, 2000:163-166).

Bejaarde deelnemers is deur middel van twee nie-waarskynlikheidseleksie-tipe steekproewe betrek, naamlik 'n doelgerigte en sneeubalsteekproef (Babbie, 2004:183-184; Strydom, 2005:201-203). 'n Doelgerigte steekproeftegniek is geïmplementeer ten einde 40 potensiële bejaarde deelnemers by geregistreerde behandelingsentra in Suid-Afrika te betrek. Die navorsers het verskeie geregistreerde behandelingsentra in Suid-Afrika gekontak en deur middel van 'n skrywe die aard, doel en omvang van die ondersoek verduidelik. Indien die onderskeie besture toestemming verleen het, het die navorsers die geregistreerde behandelingsentra besoek en potensiële deelnemers, dus alkoholafhanklike bejaardes tans op die gevallelading van die sentrum, doelgerig geselekteer. Die aard, doel en omvang van die ondersoek is aan elke potensiële deelnemer verduidelik. Indien bejaarde deelnemers skriftelik tot vrywillige deelname ingestem het, is ' $n$ gestruktureerde onderhoud van 45 minute met elke deelnemer gevoer waarin 'n profielsamestelling die oorhoofse doelwit was. Daarbenewens is 'n sneeubalsteekproef gebruik om potensiële deelnemers in die CAD en CAB by die ondersoek te betrek. Die navorsers het voorsitters van die CAD en CAB gekontak. Elke groepvoorsitter is gevra of die groep oor potensiële deelnemers vir die ondersoek beskik. Groepvoorsitter het eerstens met potensiële deelnemers gekontak, alvorens die navorsers met hul in verbinding gebring is. Tydens die navorsers se besoek aan die potensiële deelnemers is die aard, doel en omvang van die ondersoek verduidelik. Onderhoude is slegs met diegene gevoer wat hulself skriftelik tot vrywillige deelname verbind het. Na afloop van die onderhoude is deelnemers gevra of hul die navorser met ander potensiële deelnemers in verbinding (sneeubal) kan bring. In totaal is 56 deelnemers by hierdie faset van die ondersoek betrek. Die kriteria vir die insluiting van bejaarde deelnemers was soos volg:

- Alkoholafhanklike bejaardes van 58 jaar en ouer, mits hulle reeds afgetree het.

- Alkoholafhanklike bejaardes van 60 jaar en ouer, ongeag hulle werkstatus.

- Slegs potensiële deelnemers wat beskikbaar en bereid was tot deelname is betrek.

Die resultate van die bio-psigososiale en demografiese profiel word vervolgens opsommend weergegee. Vanuit die profiel blyk dit dat alkoholafhanklike bejaardes oor die volgende sterktes beskik (Geyer, 2006:48-49):

- Hulle is dikwels steeds in die eg verbind. Eggenote dien as steunstelsels vir die alkoholafhanklike bejaarde, hetsy vóór, tydens of ná behandeling.

- Verhoudings met kinders en kleinkinders is relatief stabiel. Die alkoholafhanklike bejaarde ervaar die ondersteuning van dié persone as 'n sterkte.

- Die meeste deelnemers beoefen stokperdjies. Aangesien dit afleiding, ontspanning en vermaak aan hulle bied, kan dit as 'n sterkte beskou word.

- Rolvervulling is ' $n$ sterkte in die lewens van die meeste deelnemers, want hulle meen dat hul steeds van waarde is vir die gemeenskap. Voorts impliseer dit terselfdertyd dat dié persone 'n sterkte in die gemeenskap is. 
- 'n Hunkering na iets meer betekenisvol en hoër as alkohol word bevredig deur die bejaardes se toegewyde godsdienstige en geestelike lewe. Talle deelnemers getuig dat godsdiens en geestelikheid 'n sterkte in hulle lewens is.

- Die deelnemers beskik oor 'n gemiddelde inkomste van R3000,00 plus per maand. Dit as sodanig is 'n sterkte, aangesien dit bo die heersende Suid-Afrikaanse broodlyn is.

- Verblyfomstandighede is vir 'n beduidende aantal deelnemers 'n sterkte deurdat hulle oor eie woonhuise beskik.

- Die oorgrote meerderheid deelnemers ervaar die sterkte van goeie psigiese gesondheid.

Daarbenewens het die profiel uitdagings (probleme) uitgewys. Die volgende uitdagings verteenwoordig die intervensiebehoeftes van alkoholafhanklike bejaardes (Geyer, 2006:49):

- Die huweliksverhouding van die deelnemers, wat verbeter kan word deur lewensvaardighede soos konstruktiewe kommunikasie en konflikhantering, blyk 'n uitdaging te wees.

- Verliese, soos egskeiding en die afsterwe van geliefdes, is deur talle deelnemers beleef. Alkoholafhanklike bejaardes behoort dus ' $n$ behoefte te ervaar om verliese te verwerk sodat hulle hernude veerkragtigheid kan bereik.

- Alleenlopendes is dikwels geneig tot die inname van groot hoeveelhede alkohol. Uitdagings soos hierdie kan oorbrug word deur die uitbouing van sosialiseringsvaardighede en 'n positiewe selfbeeld asook die doelgerigte beoefening van stokperdjies.

- Alkoholafhanklike bejaardes is nie meer seksueel aktief ná aftrede/bejaardheid nie, alhoewel hulle steeds oor die behoefte en vermoë daartoe beskik. Hierdie uitdaging kan oorbrug word deur die bejaardes te bemagtig met ouderdomspesifieke kennis en vaardighede oor hierdie lewensfunksie.

- Die deelnemers se sosiale lewe toon 'n afwaartse tendens. Hulle sosiale lewe kan verbeter word deur te fokus op sosialisering volgens behoefte met persone anders as die drinkmaats.

- Behoeftes aan godsdiensbeoefening binne groepverband kan oorbrug word deur die benutting en totstandkoming van groepe.

- Alkoholafhanklike bejaardes is dikwels nie meer aktief in die arbeidsmark betrokke nie, alhoewel hulle steeds positiewe bydraes wil lewer in die gemeenskap. Hierdie uitdaging kan oorbrug word deur bejaardes te bemagtig met tydsbestuursvaardighede vir die onbenutte ure van die dag, aanmoediging tot stokperdjiebeoefening en die aanwending van bejaardes as mentors vir die jonger geslag.

- Verskeie deelnemers ly aan depressie. Die bejaardes behoort met toepaslike hanteringsvaardighede toegerus te word ten einde depressie die hoof te bied.

Op grond van die sterktes en uitdagings wat die profiel aan die navorsers uitgewys het, is ' $n$ groepwerk-bemagtigingsprogram vir alkoholafhanklike bejaardes ontwikkel. Vervolgens word die programontwikkelingsfase toegelig.

\section{Fase 2: Ontwikkeling}

Bestudering van relevante data en die nuwe tegnologiese ontwerp is stappe binne hierdie fase (Strydom, 2000:157). Op grond van die bevindings in die analise fase is 'n maatskaplike groepwerk-bemagtigingsprogram, voortaan bemagtigingsprogram genoem, ontwikkel. Voorts is dit ontwikkel ooreenkomstig bemagtigende groepwerk volgens 'n sterkteperspektief (DuBois \& Miley, 2002:199; Saleebey, 2002:13-15). 
Potensiële alkoholafhanklike bejaarde groeplede, van 55 jaar en ouer ten tyde van die ondersoek, is deur middel van 'n eenvoudige ewekansige steekproef (Rubin \& Babbie, 2005:264-266) betrek uit 'n universum van 35 bejaardes. Die aanpassing van die ouderdomsperk was nodig weens die aanvanklike beperkte deelnemertal, alhoewel die gemiddelde ouderdom van die deelnemers sowat 60 jaar (60.3) ten tyde van die ondersoek was. Aanvanklik is sestien $(\mathrm{N}=16)$ bejaardes van ' $n$ geregistreerde behandelingsentrum in Gauteng in hierdie ondersoek betrek. Agt is in 'n eksperimentele groep ingesluit en aan die voorgestelde maatskaplike groepwerkbemagtigingsprogram blootgestel. Daarbenewens is agt bejaardes in ' $n$ vergelykende groep ingesluit deurdat dié lede aan die bestaande groepwerkprogram van die sentrum blootgestel is.

Die navorsers het vóór die programaanbieding met al die deelnemers $(\mathrm{N}=16)$ 'n kontrak gesluit waarin die aard en omvang van die ondersoek, etiese aspekte en praktiese implikasies uiteengesit is. Die programinhoud is soos volg:

\section{- Programinhoud}

In die onderhawige paragrawe word die oorhoofse doelstelling en programinhoud, wat vir die eksperimentele groep aangebied is, aangetoon. Die programaanbieding het op 'n weeklikse basis van 90 minute per geleentheid, oor dertien byeenkomste gestrek vanaf 31 Mei 2005 tot 17 Augustus 2005. Die program is oor 'n veel langer periode as slegs drie weke aangebied, aangesien 'n literatuurstudie die navorsers oortuig het om groepwerkprogramme vir alkoholafhanklike bejaardes teen 'n heelwat stadiger tempo aan te bied (Corey \& Corey, 1997:409-413; Toseland, 1995:28-39). Daarbenewens is die programinhoud gereduseer tot die absolute behoeftes en sterktes van die kliëntegroep, soos afkomstig vanuit die profiel. Sodoende is die bejaarde kliënte nie onnodig bemoei met temas en vaardighede waarvoor hulle nie 'n behoefte uitgespreek het nie. Elke groepbyeenkoms is begin met die evaluering van tuiswerk deur die aanwending van oplossingsgefokusde onderhoudvoeringstegnieke (Lee, 2003:389, Stalker, Levene \& Coady, 1999:468-471; Van Wormer \& Davis, 2003:81) soos "Wat doen jy nou anders in 'n konfliksituasie sedert ons ' $n$ byeenkoms aan konflikhantering afgestaan het?" Die samevatting van groepbyeenkomste is hanteer deur die aanwending van onvoltooide sinne soos "Vandag het ek geleer...." Dit word egter nie telkens in die teks aangetoon nie.

\section{Oorhoofse doelstelling van die maatskaplike groepwerk-bemagtigingsprogram}

Om 'n maatskaplike groepwerk-bemagtigingsprogram te ontwerp wat deur middel van literatuurstudie en empiriese navorsing daarop gerig is om die maatskaplike funksionering van alkoholafhanklike bejaardes te verbeter en hulle sterktes uit te bou.

\section{Byeenkoms 1: Ontmoeting en oriëntering}

Die maatskaplike werker, voortaan fasiliteerder genoem, en al die groeplede het aan die kenverhouding aandag geskenk deur hulself aan mekaar voor te stel. 'n Vertrouensverhouding is opgebou deur etiese oorwegings in Maatskaplike Werk (Cournoyer, 1996:58), soos die verpligting van maatskaplike werkers om die privaatheid van kliënte te respekteer en bespreek. Hierdie etiese oorwegings is bespreek sodat 'n alkoholafhanklike bejaarde, wat geneig is tot agterdog, kon weet dat hy slegs dit waarmee hy gemaklik voel, met die groep hoef te deel.

Groeplede het vir hulself, en die fasiliteerder, groepreëls neergelê. Elke groeplid het die meetinstrument, Short Michigan Alcohol Screening Test-Geriatric Version (SMAST-G), ontvang om te voltooi (Blow et al. in Oslin \& Holden, 2002:24). Hierdeur is groeplede uitgedaag om (a) individueel te bepaal of hy 'n alkoholafhanklike persoon is, en (b) deur selfondersoek te besluit of hy die uitdaging aanvaar om daarvan te ontspring. Vennootskap en 
eienaarskap, as beginsels van 'n sterkteperspektief (Kisthardt, 2002:164-172), is in die groepwerkproses toegepas met 'n versoek aan die groeplede om aan te dui watter onderwerpe hulle graag wil bespreek. Die groepinsette, tesame met dié van die fasiliteerder (gegrond op resultate van die empiriese ondersoek soos vroeër bespreek), het gelei tot die sluiting van 'n kontrak vir dertien groepbyeenkomste, rakende elf onderwerpe. Twee gestandaardiseerde meetinstrumente, die verkorte Affectometer 2, asook Personal Multi-Screening Inventory (PMSI), is individueel voltooi vir die doeleindes van 'n voortoetsmeting.

\section{Byeenkoms 2: Alkoholafhanklikheid: wat, waarom en die gevolge?}

Alkoholisme is gedefinieer in die groeplede se eie woorde. Hierdie aktiwiteit is ingesluit om (a) die beginsel dat die kliënt se eie woorde en omskrywing van sy uitdagings belangrik is, te erken (Geyer, 2003:103), terwyl (b) dit aansluit by maatskaplikewerk-dienslewering binne 'n sosiale konstruksionisme, waaruit die sterkteperspektief ontwikkel het (Dean, 1993:57-58; Lee, 1996:188,198-199; Witken, 1990:37-40). Hierdie aktiwiteit is saamgevat met 'n gestandaardiseerde definisie soos vervat in die Tweetalige Definiërende Woordeboek vir Maatskaplike Werk (Vaktaalkomitee vir Maatskaplike Werk, 1984:3). Die akute gevolge van alkoholmisbruik is op 'n didaktiese wyse aan die groeplede voorgehou met herhaaldelike motiverings om insette te lewer. Die onmiddellike uitwerking van alkohol, op die sentrale en perifere senuweestelsel, kognisie, gemoedstoestand asook sensoriese en motoriese aktiwiteit, is bespreek aan die hand van Barlow en Durand (1999:343-345), Goode (1993:157-161), Jung (1994:32-42, 57-69) asook Louw (1993:59-94). Die oorsake en gevolge van alkoholmisbruik (Geyer, 2003:75-76, 84-88; Joubert, 2002:15,19-22) is met die groep bespreek sodat hulle enersyds tot insig kon kom wat tot hul individuele afhanklikheid aanleiding gegee het, en andersyds die voordele van alkoholonthouding kon insien.

\section{Byeenkoms 3: Selfbeeld}

' $n$ Positiewe selfbeeld is van belang vir elke persoon sodat sy lewenskwaliteit en maatskaplike funksionering voortdurend kan verbeter (Roux, 2002:223). Derhalwe is elke groeplid die geleentheid gebied om sy selfbeeld te evalueer met behulp van 'n vraelys (Nasionale Raad vir Geestesgesondheid, 1990), alvorens 'n omvattende groepgesprek gevolg het.

Die begrip, selfbeeld, is bespreek en omskryf om verwarring te voorkom. Wessels (1996:84) haal Higgins aan wat selfbeeld soos volg definieer: "Jou selfbeeld is dit wat jy dink van jou voorkoms, intelligensie, prestasievermoë, interpersoonlike verhoudings en ook jou idee van wat ander van jou dink. Selfbeeld is die siening wat 'n persoon van homself het, nadat hy homself geëvalueer het." Vir die doeleindes van hierdie byeenkoms is die voorgenoemde definisie as uitgangspunt gebruik. Fasette van die selfbeeld is bespreek, waarna groeplede met behulp van 'n selfdoenoefening hulle negatiewe en positiewe selfbeeldeienskappe kon neerskryf. Die uniekheid van elke groeplid is ingeskerp met die volgende slagspreuk: "God made me and God don't make junk!" (Cilliers in Roux, 2002:224). Deur middel van 'n groepgesprek is beide die positiewe en negatiewe kenmerke van die selfbeeld verken volgens Roux (2002:225-226), Strydom (1990:208-209) en Wessels (1996:86-88). Die byeenkoms is tot 'n hoogtepunt gevoer met die versoek aan groeplede om maniere te bedink waarvolgens 'n negatiewe selfbeeld verander kan word. Die voorgenoemde gesprek is aangevul vanuit die literatuur (Roux, 2002:227; Strydom, 1990:211-212; Van Jaarsveld, 2003:38-49, 56-57). Hierdie aktiwiteite beantwoord aan een van die sterkteperspektief se beginsels, naamlik dat omvattende eksplorering tussen die kliënt en maatskaplike werker noodsaaklik is, sodat die kliënt bewus kan word van die sterktes waaroor hy beskik om sy uitdagings te hanteer (Geyer, 2003:104). 
Elke groeplid moes vir tuiswerk opstelle van 250 woorde elk skryf oor die onderwerpe " $M y$ lewe..." en "Vanaf vandag die toekoms in ...."

\section{Byeenkoms 4: Tydsbestuur}

Tydsbestuur is in groeplede se eie woorde omskryf. Hierdie faset van die groepgesprek is aangevul uit die literatuur (Thompson, 2002:12-14). Groeplede is in twee kleiner groepe verdeel met die opdrag om soveel moontlik maniere vir effektiewe tydsbestuur te bedink en dit aan te teken. Voorts moes een persoon per groep die resultate aan die groter groep voorhou. Hierdeur is die groeplede se sterkte tot selfvertroue en kommunikasie in die openbaar bevorder. Die fasiliteerder het eweneens metodes, soos geïdentifiseer deur Thompson (2002:14-17), aan die groep voorgehou. Daar is van die veronderstelling uitgegaan dat die bejaarde persoon nie slegs ' $n$ behoefte aan tydsbestuursvaardighede mag ervaar nie, maar ook om energievlakke optimaal te hou. In die lig van die voorafgaande is effektiewe energiebeheer in groepverband en deur die fasiliteerder bespreek. Voorts is dié gesprek aangevul met die literatuur (Thompson, 2002:18-20). Die kennisvlak van die groeplede is uitgebou met toepassings in die praktyk deurdat groeplede versoek is om twee scenario's op te los met betrekking tot tyds- en energiebestuur. Vir tuiswerk moes die groeplede 'n dagboek byhou vir een werksdag en een naweekdag sodat hulle verder oor die onderwerp kon nadink.

\section{Byeenkoms 5: Kommunikasie}

'n Ysbreker, telefoontjie, is benut om die onderwerp in te lei. Deur dié oefening het groeplede tot die besef gekom dat, ofskoon kommunikasie 'n alledaagse vaardigheid is, dit dikwels kan skeefloop. Groeplede het kommunikasie in hul eie woorde omskryf, voordat Alpaslan (1994:72) se definisie aan die groep voorgehou is. Die vernaamste elemente van kommunikasie, naamlik die bron, boodskap en bestemming, is bespreek volgens Alpaslan (1994:176179) en Nicol (2000:49-51). Struikelblokke in kommunikasie is bespreek sodat groeplede bewus kon word van dié uitdagings en maniere kon bedink om dit te oorkom. Slegs ses struikelblokke, soos stiltes wat 'n atmosfeer van vyandigheid skep (Wessels, 1996:65-66), is bespreek. Groeplede is deurgaans aangemoedig om die gesprek te verryk met voorbeelde vanuit hulle eie leefwêreld. Wyses ter bevordering van kommunikasie is ook bespreek (Alpaslan, 1994:78-80; Nicol, 2000:66-74). Die fasiliteerder het die groep versoek om 'n uitdagende kommunikasiegeleentheid te bedink, waarna vrywilligers dit in 'n rollespel kon uitbeeld. Dit was betekenisvol dat die groep reeds 'n konfliksituasie bedink het, alhoewel dié onderwerp nog nie aangeraak is nie.

Vir tuiswerk is groeplede aangemoedig om in die komende week op hulle kommunikasie te let en ten minste een positiewe en een negatiewe eienskap te identifiseer. Hierdie oefening het die toepassing van dié vaardigheid gestimuleer en hopelik volhoubare groei bevorder.

\section{Byeenkoms 6: Konflikhantering}

Ter aanvang is 'n aanhaling van Van Jaarsveld (2003:71) voorgelees ten einde 'n aanknopingspunt vir die tema te vind. In die gelese gedeelte is verduidelik hoedat oudpresident Nelson Mandela, ná 27 jaar in die tronk, 'n roete van demokrasie en versoening in Suid-Afrika gevolg het, eerder as tirannie. Groeplede het 'n groepgesprek gevoer rondom die omvattende ervaring van konflik. Aspekte, soos die oorsaak, redes en uitdrukking van woede, is bespreek (Kleinke, 1998:133-135). Daarna het die dimensies van konflik, byvoorbeeld negatiewe emosies wat tot spysverteringsprobleme kan lei, aan die beurt gekom (Van Jaarsveld, 2003:7173). Verskillende riglyne vir konstruktiewe konflikhantering is aan die groeplede voorgehou sodat hulle dit met vrug in hul eie leefwêreld kan toepas. Riglyne, soos ontspanningstegnieke 
en die benutting van humor, is uitgelig (Alpaslan, 1994:87-88; Kleinke, 1998:140-142, 153163; Van Jaarsveld, 2003:76-78). Die voorafgaande besprekings is voortdurend aangevul met insette deur die groeplede. Die kennisbasis van die byeenkoms is uitgebou tot die praktiese toepassing van konflikhanteringsvaardighede binne die veilige terapeutiese milieu. Die groep is aangemoedig om 'n konfliksituasie te bedink sodat dit deur rollespel uitgebeeld kon word (Toseland \& Rivas, 2001:301). Selfontspanningstegnieke is vir die groep aangeleer met instruksies van die fasiliteerder.

\section{Byeenkoms 7: Hantering van ligte depressie}

Vir die doeleindes van hierdie byeenkoms verwys die begrip, ligte depressie, na 'n toestand van swaarmoedigheid. Dit verwys nie na die siektetoestand wat psigologiese en mediese behandeling vereis nie. 'n Ysbreker, bestaande uit die voorspeel van ses musiekfragmente wat verskillende emosies behoort te ontlok, is met die groep onderneem. Op grond van die werk van De Swart en Hofmeyer (1990:122) asook Kruger en Pieterse (2004:399-411) is musiekfragmente soos Vocalise van S Rachmaninov voorgespeel om 'n emosionele toestand van kalmte te verkry. 'n Werkkaart is benut waarop groeplede individueel hul emosies aangeteken het soos ontsluit deur die musiek, voordat dit in groepverband bespreek is. Die vernaamste simptome van depressie, onder andere selfmoordgedagtes (Kleinke, 1998:73), is aan die groep voorgehou. Elke groeplid is die geleentheid gebied om sy hantering van depressie te bepaal aan die hand van die Depression coping questionnaire (Kleinke, 1998:81). Vanuit die resultate kon bestaande en alternatiewe sterktes ten opsigte van konstruktiewe depressiehantering ontdek word. Die konstruktiewe hantering van depressie is bespreek met die teks van Kleinke (1998:75-92) en Van Jaarsveld (2003:102-110) as riglyne. Groeplede is gemotiveer om insette te lewer en vir hul sterktes, soos lewenskennis en -wysheid, is erkenning gegee.

Vir tuiswerk moes elke groeplid 'n opstel skryf oor 'n krisis in sy lewe wat tot depressie aanleiding gegee het. Daarna moes die groeplid vir homself aandui (a) wat hy daaruit geleer het, en (b) hoe hy dit in die toekoms positief kon aanwend. Die rede hiervoor was om veerkragtigheid ("resiliency") te ontsluit.

\section{Byeenkoms 8: Hantering van verlies}

Die fasiliteerder het twee groeplede aangemoedig tot 'n narratief van verlies. Die doel van die narratiewe was om risikofaktore (faktore wat doeltreffende verlieshantering verhoed) en beskermingsfaktore (faktore wat doeltreffende verlieshantering bevorder) te identifiseer. Die rede hiervoor was om heling en heelheid te stimuleer deur na mekaar se narratiewe te luister (Dean, 1998:25-26). Die fasiliteerder het die fases van verlies met die groep bespreek aan die hand van Kübler-Ross (Janson \& König, 2002:77-82; Kübler-Ross, 2003:34-121). Die doel hiervan was om groeplede tot die besef te bring dat verlieshantering inspanning verg en nie 'n passiewe belewenis is nie. Een van die fases, naamlik woede, is deur die groeplede uitgesonder.

Met behulp van 'n uitvissingstegniek ("probing”) is groeplede uitgelok om maniere vir effektiewe verlieshantering te vermeld. Hierdie aktiwiteit het gelei tot 'n bespreking van konstruktiewe hanteringstrategieë, soos 'n begrafnisritueel en positiewe denke, vir verlies (vgl. Kleinke, 1998:181-182). Vir tuiswerk is groeplede versoek om 'n simbool van verlies vir iemand te skep, byvoorbeeld 'n gedig, ten einde verlieshantering te stimuleer.

\section{Byeenkoms 9: Vreugdes en uitdagings van seks in bejaardheid}

Die byeenkoms is aangebied in samewerking met ' $n$ geregistreerde verpleegkundige vanweë die multidissiplinêre aard van die onderwerp. Voorts is slegs op die manlike geslag gefokus, vanweë die afwesigheid van vroulike groeplede. Elke groeplid het 'n kopie van die ASKAS- 
vraelys (White in Hillman, 2000:34-35) ontvang om te voltooi sodat die verpleegkundige die groep se eiesoortige behoeftes en uitdagings rondom seksuele aangeleenthede kon peil. Die vernaamste dele van die manlike anatomie is bespreek met behulp van sketse. Kennis van die manlike anatomie is nodig om uitdagings van seks tydens bejaardheid beter te begryp. Die seksresponssiklus van die ouer manlike persoon (Crooks \& Baur, 2002:170-171) is bespreek, terwyl groeplede aangemoedig is om sinvolle bydraes te lewer.

Met behulp van 'n uitvissingstegniek is vasgestel watter seksuele uitdagings die groeplede beleef. Uitdagings, soos impotensie, is bespreek (Alpaslan, 1994:50-51; Crooks \& Baur, 2002:445-449). Die fisiese en psigiese oorsake van seksuele uitdagings, soos depressie wat tot impotensie kan lei, is toegelig aan die hand van verskeie outeurs se standpunte (Crooks \& Baur, 2002:428-441; Hillman, 2000:144-148; Masters, Johnson, \& Kolodny, 1988:518-519). Oplossings hiervoor, soos die gebruik van medikasie, is eweneens bespreek (Crooks \& Baur, 2002:460-470; Hillman, 2000:151-154).

Vir tuiswerk het elke groeplid geskrewe instruksies ontvang om 'n manlike genitalieë selfondersoek uit te voer. Die doel hiervan was om die groeplede met die vaardigheid van dié selfondersoek toe te rus ter voorkoming/vroeë behandeling van moontlike mediese toestande.

\section{Byeenkoms 10: MIV/VIGS en die bejaarde persoon}

Die byeenkoms is in samewerking met ' $n$ geregistreerde verpleegkundige aangebied. Alhoewel geen bejaarde deelnemer gerapporteer het dat hy/sy MIV-positief is nie, is 'n byeenkoms aan dié siektetoestand gewy op versoek van die sentrumbestuur en die groeplede. Die rede hiervoor is tweërlei: Eerstens ter voorkoming van 'n lewensbedreigende pandemie. Tweedens ter voorkoming van moontlike infektering aangesien persone onder die invloed van alkohol riskante seksuele gedrag openbaar. Ter aanvang is die aard en omvang van MIV/Vigs in Suider-Afrika op 'n didaktiese wyse aan die groep voorgehou (Roux, 2002:47-50,193-195). Laasgenoemde outeur se inligting is gebruik omdat dit relatief resent is en reeds in maatskaplike groepwerk toegepas en doeltreffend bevind is. Ooreenkomstig beginsels van sosiale konstruksionisme is MIV/Vigs omskryf in groeplede se eie woorde, waarna dié faset afgesluit is met Roux (2002:18-19) se definisies. Die maatskaplike werker en verpleegkundige het die oorsake en gevolge van MIV/Vigs vir die individu en gesin bespreek (Crooks \& Baur, 2002:502-506, 512-513; Jones, 1997:469-474; Roux, 2002:57-62, 196-202). Daarbenewens is tipiese mites rondom MIV/Vigs die nek ingeslaan, byvoorbeeld dat MIV deur eetgerei oorgedra word. Die maatskaplike werker het prakties aan die groep gedemonstreer hoe om 'n manlike kondoom te gebruik met behulp van 'n dildo. Die doel hiervan was om die groeplede met praktiese vaardighede te bemagtig rondom die toepassing van 'n voorkomingsmaatreël vir MIV/Vigs infeksie/her-infektering. Voorts is alternatiewe maatreëls, soos getrouheid aan een seksmaat en die vermyding van seksuele vloeistowwe, bespreek (Van Dyk, 2001:142-144).

Die maatskaplike werker het vir tuiswerkdoeleindes 'n blokkiesraaisel ontwerp wat groeplede moes voltooi. Hierdie gewilde stokperdjie van bejaardes is gebruik om op 'n interessante en bekende manier groeplede se kennis oor die onderwerp te toets.

\section{Byeenkoms 11: Godsdiens en geestelikheid in bejaardheid ${ }^{1}$}

Hierdie byeenkoms is in samewerking met 'n leraar aangebied, vanweë die multidissiplinêre aard van die onderwerp. Geen groeplid is gedwing om die byeenkoms by te woon nie. Voorts is

\footnotetext{
${ }^{1}$ Geestelikheid verwys na die belewenis van God/god se teenwoordigheid, terwyl godsdiens op die rituele van godsdiensbeoefening dui.
} 
daar slegs op die christelike geloof gefokus aangesien geen groeplid homself met ' $n$ ander geloofsoortuiging geïdentifiseer het nie. 'n Aantal oop vrae, byvoorbeeld "Is alkoholmisbruik sonde?", is aangewend om die tema te ontsluit.

Die leraar het die Gelykenis van die verlore seun (Lukas 15:11-32) aan die groep voorgehou deur middel van 'n opvoedkundige groepwerkbenadering. Dié benadering is gebruik om inligting aan die groep deur te gee (Toseland \& Rivas, 2001:25). Groeplede is steeds op allerlei maniere, soos oop vrae, aktief by bespreking betrek om moontlike onaktiewe groeplede uit te skakel (Geyer, 2003:132). Die gelykenis is gebruik om groeplede daarop te wys dat, indien alkohol hulle van God vervreem het, hulle steeds die geleentheid het om terug te keer na die die christelike geloof en lewenswandel. Daarbenewens is bestanddele vir die herstel of verdieping van godsdiensbeoefening, soos belydenis van sonde en die aanvaarding van vergifnis, aan die groep voorgehou. Die maatskaplike werker het 'n uitvissingstegniek benut ten einde van die groeplede te verneem hoe hulle meen 'n individuele verhouding met God uitgebou kan word. Op hierdie wyse is daar erkenning gegee aan groeplede se kennis van en insig in die onderwerp. Vir tuiswerk, en ter voorbereiding vir die volgende groepbyeenkoms, moes Te vroeg vir moedverloor, deur Izak de Villiers (2000:189-192), gelees word.

\section{Byeenkoms 12: Terugvalvoorkoming en toekomsbeplanning}

Die groeplede is versoek om die begrippe, terugval en glips, in hulle eie woorde te verduidelik. Voorts is ' $n$ uitvissingstegniek aangewend om groeplede aan te moedig om die begrippe toe te lig met werklike lewensgebeure. Die faset is saamgevat met twee definisies vanuit die literatuur. Groeplede is daarop gewys dat 'n terugval/glips normaal deel vorm van die herstelproses in alkoholisme (Joubert, 2002:91; Van Wormer \& Davis, 2003:202). Die oorsake van 'n terugval op die inter- en intrapersoonlike vlak (Joubert, 2002:98) is in groepverband bespreek.

'n Terugvalmodel is aan die groeplede voorgehou (Marlatt \& Gordon in Joubert, 2002:94). Dié model is gesetel in die kognitiewe gedragsanalise. Barrick en Connors (2002:588) meen dat kognitiewe gedragshandelinge besonder geskik is vir terugvalvoorkoming met alkoholafhanklike bejaardes. Juis om hierdie rede is sodanige model aan die groep voorgehou, alhoewel die inherente uitgangspunte van dié denkskool verskil van 'n sterkteperspektief. Daarna is strategieë, soos die bywoning van ondersteuningsgroepe van die AA of CAD (Barnard, 1998:31; Barrick \& Connors, 2002:588-592; McGinnis, 2002:193-210; Van Wormer \& Davis, 2003:202), ter voorkoming van 'n terugval bespreek. Daarbenewens is die groeplede gemotiveer om verskillende sterktes, soos 'n huweliksmaat, te identifiseer wat as buffers teen terugvalle kan dien (Abrams, 2001:283-286; Fraser \& Richman, 1999:2-4; Henderson, 2002:17; Waller, 2001:5).

Vir tuiswerk het elke groeplid 'n blanko toekomsbeplanning (nugterheidsplan) ontvang om te voltooi. Dié hulpmiddel is aangepas uit die werk van Rapp (1998:101-126). Die doel van die oefening is om suksesvolle toetrede tot die gemeenskap te bewerkstellig. Voorts het hierdie oefening die groeplede gemobiliseer om gemeenskapshulpbronne te identifiseer wat hulle suksesvolle toetrede tot die gemeenskap kan bevorder. Dit sluit effektief aan by 'n beginsel van die sterkteperspektief, naamlik dat alle gemeenskappe, hoewel in wisselende grade, oor hulpbronne beskik (Geyer, 2003:103). Groeplede is voorberei op terminering met die versoek om terug te dink oor die reeks byeenkomste sodat enkele slotgedagtes met die groep gedeel kon word. 


\section{Byeenkoms 13: Afsluiting, evaluering en afsluitingseremonie}

'n Terugskouing oor die aard, inhoud en omvang van die program is hanteer. 'n Tegniek van Corey, Schneider-Corey, Callanan en Russell (1992:157-158) is benut om terugvoer oor die waarde van die program, gebaseer op die mening van die groeplede, in te samel. Die groeplede is versoek om in hulle geestesoog 'n "video" te sien afspeel van die reeks byeenkomste. Hulle is aangemoedig om aan te dui wat hulle van die program onthou asook aan te toon wat vir hulle aangenaam en minder aangenaam was. Voorts is die groeplede se emosies insake terminering hanteer. Elke groeplid moes die volgende sin voltooi: "Ek voel ... oor vandag se afsluiting van ons groep." Hierdie oefening is gebruik omdat dit enersyds groeplede se sterkte ontwikkel om emosies te kommunikeer (Geyer, 2003:193), en andersyds motiveer tot die toepassing van dit wat tydens die program hanteer is (Corey et al., 1992:157-158). 'n Groot boom is op 'n bord geteken. Daarna het die fasiliteerder die groep daarop gewys dat 'n boom aan sy vrugte geken word (vgl. Matteus 12:33-36). Voorts is 'n breinstormtegniek benut om sterktes wat groeplede meen tydens die program ontwikkel en/of verfyn is, te identifiseer en te motiveer. Die genoemde sterktes is as vrugte op die boom aangebring. Ná die oefening het die fasiliteerder die groeplede gemotiveer om elke dag met moed en ywer hierdie "vrugte" te dra en die "boom" (die self) te voed met betekenisvolle andere en hulpbronne in die gemeenskap asook sterktes in die self.

Die program is omvattend geëvalueer deurdat elke groeplid individueel twee gestandaardiseerde meetinstrumente voltooi het. Daarbenewens is 'n selfopgestelde vraelys, ontwerp deur die navorsers, eweneens voltooi. Elke groeplid het 'n sertifikaat ontvang wat erkenning gee vir sy deelname aan die program. Selekman (1991:47-48) meen só 'n afsluitingseremonie hou groot motiveringswaarde in vir elke groeplid.

Vervolgens volg nadere besonderhede insake die evalueringsfase.

\section{Fase 3: Evaluering}

In hierdie fase word die nuwe produk aan 'n voorlopige veldimplementering onderwerp sodat die voorlopige resultate bekend kan word (Strydom, 2000:157). Sestien (N=16) alkoholafhanklike bejaarde mans, wat ten tyde van die ondersoek reeds by 'n langtermynbehandelingsprogram betrokke was en reeds 'n behandelingsgeskiedenis gehad het, is by die ondersoek betrek. Soos by fase 2 vermeld is, is agt deelnemers $(\mathrm{N}=8)$ in 'n eksperimentele groep, en dieselfde getal $(\mathrm{N}=8)$ in 'n vergelykende groep opgeneem. Slegs manlike deelnemers is betrek weens die afwesigheid van vroulike deelnemers in die betrokke behandelingsentrum.

Soos in die programinhoud aangetoon is, is die effek van die bemagtigingsprogram met behulp van twee gestandaardiseerde meetinstrumente getoets voor en na programaanbieding. Daarbenewens is ' $n$ selfopogestelde vraelys ook deur die eksperimentele groep voltooi na afloop van die bemagtigingsprogram. Die vergelykende groep, wat die sentrum se bestaande groepwerkprogram deurloop het, het dieselfde gestandaardiseerde meetinstrumente voltooi voor en na hul program. Geen selfopgestelde vraelys was op die laasgenoemde groep van toepassing nie. Beide groepe het ses maande na afloop van die onderskeie programme weer eens die twee gestandaardiseerde meetinstrumente voltooi. Dit is egter nie die doel van hierdie artikel om die aard en inhoud van die meetinstrumente, of resultate van die bemagtigingsprogram breedvoerig te bespreek nie, maar eerder die programontwikkeling en -inhoud. Nietemin, die navorsers het tot die volgende opsommende bevindings gekom ten opsigte van die programresultate (Geyer, 2006:159-161): 
- Volgens die resultate van die gestandaardiseerde meetinstrumente het nóg die bemagtigingsprogram, nóg die bestaande groepwerkprogram daarin geslaag om die maatskaplike funksionering van die bejaarde deelnemers statisties beduidend $(p>0,05)$ te verbeter.

- Die resultate van die selfopgestelde vraelys dui daarop die eksperimentele groep se maatskaplike funksionering verbeter het, deurdat die deelnemers meen dat hul sterktes toegeneem het. Voorts dui die resultate daarop dat die eksperimentele groep se hanteringsvaardighede, om hul uitdagings te hanteer, verbeter het. Die laasgenoemde vraelys het dit egter nie geleen tot statistiese ontleding om vir statistiese beduidenheid te toets nie.

Die verspreidingsfase van die navorsingsmodel is soos volg onderneem.

\section{Fase 4: Verspreiding}

Hierdie fase bestaan uit twee elemente: Eerstens word nuwe tegnologie voorberei vir publikasie en tweedens, beskikbaar gestel aan verbruikers (Strydom, 2000:158). Resultate van hierdie ondersoek is reeds tydens gedurende 2006 aangebied tydens die $\mathbf{3 3}^{\text {rd }}$ World Congress van die International Association of Schools of Social Work (IASSW) te Santiago, Chili, asook die nasionale kongres van die Association of South African Social Work Education Institutions (ASASWEI) te Thohoyandou. Die laaste fase van die navorsingsproses bestaan uit die aanvaarding van die nuwe tegnologie.

\section{Fase 5: Aanvaarding}

Aanvaarding word gekenmerk deur die wye benutting van die nuwe tegnologie (Strydom, 2000:158). Hierdie fase val egter buite die bestek van hierdie ondersoek.

Etiese oorwegings soos geen ongerief aan die deelnemers, ingeligte skriftelike toestemming tot deelname asook die handhawing van vertroulikheid was op elke fase van hierdie ondersoek van toepassing (Mitchell \& Jolley, 2001:138-139; Monette, Sullivan \& DeJong, 2005:53-61). Deelnemers is aan geen ongerief blootgestel nie deurdat elke deelnemer die reg gehad het om vrae onbeantwoord te laat. Voorts kon deelnemers te eniger tyd deelname aan die onderhoud, groepwerkprogram of voltooiing van meetinstrumente beëindig. Deelnemers is telkens uitgenooi tot katarsis ná die onderhoud en deelname aan die groepwerkprogram. Geen deelnemer is by ' $n$ onderhoud of die bemagtigingsprogram betrek alvorens elkeen individueel deeglik ten opsigte van die aard en omvang van die ondersoek georiënteer is nie. Daarbenewens is geen deelnemer by die ondersoek ingesluit sonder 'n skriftelike vrywaringsvorm nie. Die navorsers het deurentyd van kodes gebruik gemaak om respondente se anonimiteit te verseker en vertroulikheid te handhaaf.

\section{GEVOLGTREKKINGS}

Op grond van die voorafgaande bevindings en besprekings word daar tot die volgende gevolgtrekkings gekom:

Daar is ' $n$ omvattende ondersoek met alkoholafhanklike bejaardes onderneem wat gelei het tot die samestelling van 'n omvangryke bio-psigososiale en demografiese profiel waarin verskeie behoeftes, sterktes en uitdagings van dié kliëntegroep geïdentifiseer is. Gegrond op dié bevindings, tesame met 'n literatuurstudie en die verkenning van bestaande groepwerkinisiatiewe, is dertien groepwerkbyeenkomste saamgestel. Daar word tot die gevolgtrekking gekom dat maatskaplike groepwerk, as 'n primêre metode in maatskaplike werk, aangewend kan word om tot die werklike bio-psigososiale en demografiese omstandighede van alkoholafhanklike bejaardes te spreek. 
Volgens die kwantitatiewe data, afkomstig van die verkorte Affectometer 2 en Personal MultiScreening Inventory, kon nie die bemagtigingsprogram of bestaande groepwerkprogram daarin slaag om die bejaarde deelnemers se maatskaplike funksionering te verbeter nie. Op grond van die kwantitatiewe data word daar tot die gevolgtrekking gekom dat alkoholafhanklike bejaardes 'n swak prognose toon en nie positief reageer op groepwerkprogramme nie.

Kwalitatiewe data, afkomstig van 'n selfopgestelde vraelys, het resultate opgelewer waarvolgens dit blyk dat die eksperimentele groep positief gereageer het op die bemagtigingsprogram deurdat hulle sterktes toegeneem het, terwyl die bejaardes se hanteringsvaardighede verbeter het. Op grond van dié bevindings word die gevolgtrekking gemaak dat die bemagtigingsprogram positiewe resultate tot gevolg gehad het.

\section{AANBEVELINGS}

Op grond van die voorafgaande bevindings en gevolgtrekking word die volgende aanbevelings gemaak:

Maatskaplikewerk-praktisyns behoort groepwerkdienste aan kliënte, soos alkoholafhanklike bejaardes, te ontwikkel op grond van wetenskaplike bevindings. Voorts behoort die kliënte se standpunte oor hul eie behoeftes en uitdagings effektief geakkommodeer te word. 'n Voorbeeld hiervan sou wees om insette insake programinhoud van kliënte, as vennote in die bemagtigingsproses, toe te laat en te verwelkom.

Die voorgenoemde program behoort ook aangebied te word in 'n vrouegroep en 'n groep met beide geslagte sodat die sukses, al dan nie, daarvan in verskillende praktyksituasies bepaal kan word.

\section{SLOTOPMERKINGS}

Maatskaplike groepwerk, volgens die beginsels van 'n sterkteperspektief, kan sinvol benut word ten einde tegnologie te ontwikkel wat gerig is op alkoholafhanklike bejaardes se unieke behoeftes en sterktes. Die DR\&U-model kan met vrug gebruik word om die proses van programontwikkeling en -implementering te rig. Verdere navorsing is nodig ten einde die effek van maatskaplike groepwerk-bemagtigingsprogramme, ooreenkomstig 'n sterkteperspektief, op alkoholafhanklike bejaardes te toets.

\section{BIBLIOGRAFIE}

ABRAMS, M.S. 2001. Resilience in ambigious loss. American Journal of Psychotherapy, 55(2):283-291.

ALPASLAN, N. 1994. Hoop en hulp vir die huwelik. Pretoria: Kagiso.

BABBIE, E. 2004. The practice of social research $\left(10^{\text {th }} \mathrm{ed}\right)$. Belmont, CA: Wadsworth/Thomson Learning.

BARLOW, D.H. \& DURAND, V.M. 1999. Abnormal psychology: an integrative approach $\left(2^{\text {nd }}\right.$ ed). Pacific Grove, Calif.: Brooks/Cole.

BARNARD, A.J. 1998. Hoe hanteer ek versoekings? In: VENTER, N. (red) CAD werkboek vir die fasilitering van gesprekvoerings. Wes- en Suid-Kaapse Gebiedskomitee van die Christelike Afhanklikheidsdiens.

BARNEA, Z. \& TEICHMAN, M. 1994. Substance misuse and abuse among the elderly: implications for social work intervention. Journal of Gerontological Social Work, 21(3/4):133-148. 
BARRICK, C. \& CONNORS, G.J. 2002. Relapse prevention and maintaining abstinence in older adults with alcohol-use disorders. Drugs Aging, 19(8):583-594.

BARRIE, K. 1990. Helping in groups. In: COLLINS, S., (ed.) Alcohol, social work and helping. London: Tavistock/Routledge.

BEAVER, M.L. \& MILLER, D.A. 1992. Clinical social work practice with the elderly $\left(2^{\text {nd }}\right.$ ed). Belmont, Calif.: Wadsworth.

BRÜMMER, T. 2004. Alkohol 'is SA se nr. 1-dwelm’. Rapport: 23, 19 September.

COREY, G., SCHNEIDER-COREY, M., CALLANAN, P. \& RUSSELL, J.M. 1992. Group techniques $\left(2^{\text {nd }}\right.$ ed). Pacific Grove, Calif.: Brooks/Cole.

COREY, M.S. \& COREY, G. 1997. Groups: process and practice ( $5^{\text {th }}$ ed). Pacific Grove, Calif.: Brooks/Cole.

COURNOYER, B. 1996. The social work skills workbook ( $2^{\text {nd }}$ ed). Pacific Grove, Calif.: Brooks/Cole.

COX, A.L. 2001. BSW students favor strengths/empowerment-based generalist practice. Families in society, 82(3):305-313.

COX, E.O. \& PARSONS, R.J. 1994. Empowerment-oriented social work practice with the elderly. Pacific Grove, Calif.: Brooks/Cole.

CROOKS, R. \& BAUR, K. 2002. Our sexuality ( $8^{\text {th }}$ ed). Pacific Grove, Calif.: WadsworthThomson Learning.

DEAN, R.G. 1993. Teaching a constructivist approach to clinical practice. Journal of Teaching in Social Work, 8(1/2):55-75.

DEAN, R.G. 1998. A narrative approach to groups. Clinical Social Work Journal, 26(1):2337.

DEBLINGER, L. 2000. Alcohol problems in elderly. Patient Care, 34(19):70-86.

DE SWART, G. \& HOFMEYER, L. 1990. Die gebruik van musiek ten einde te reflekteer in maatskaplike groepwerk. Maatskaplike Werk/Social Work, 26(2):115-123.

DE VILLIERS, I. 2000. Te vroeg vir moedverloor. Kaapstad: Tafelberg.

DUBOIS, B. \& MILEY, K.K. 2002. Social work: an empowering profession $\left(4^{\text {th }}\right.$ ed $)$. Boston: Allyn and Bacon.

DUNNE, F.J. 1994. Misuse of alcohol or drugs by elderly people. BMJ, 308:608-609.

FAST, B. \& CHAPIN, R. 2002. The strengths model with older adults. In: SALEEBEY, D. (ed) The strengths perspective in social work practice $\left(3^{\text {rd }}\right.$ ed). Boston: Allyn and Bacon.

FOUCHÉ, C.B. \& DE VOS, A.S. 2005. Problem formulation. In: DE VOS, A.S. (ed) Research at grass roots $\left(3^{\text {rd }} \mathrm{ed}\right)$. Pretoria: Van Schaik.

FRASER, M.W. \& RICHMAN, J.M. 1999. Risk, protection and resilience: toward a conceptual framework for social work practice. Social Work Research, 23(3):131-143. Available: Academic Search Premier [Retrieved: 27 Jan. 2003]. 
GEYER, L.S. 2003. Maatskaplike groepwerk aan alkoholafhanklike bejaardes ooreenkomstig die sterkteperspektief. Potchefstroom: PU vir CHO. (Verhandeling $\mathrm{MA}(\mathrm{MW}))$

GEYER, L.S. 2006. Evaluering van 'n maatskaplike groepwerk-bemagtigingsprogram met alkoholafhanklike bejaardes: 'n sterkteperspektief. Potchefstroom: NoordwesUniversiteit. (Proefskrif - PhD)

GIORDANO, J.A. \& BECKHAM, K. 1985. Alcohol use and abuse in old age: an examination of type II alcoholism. Journal of Gerontological Social Work, 9(1):65-83.

GOODE, E. 1993. Drugs in American society (4 ${ }^{\text {th }}$ ed). New York: McGraw-Hill.

GRAYBEAL, C. 2001. Strengths-based social work assessment: transforming the dominant paradigm. Families in Society, 82(2):233-242.

GURNACK, A.M. \& HOFFMAN, N.G. 1992. Elderly alcohol misuse. International Journal of the Addictions, 27(7):869-878.

GURNACK, A.M. \& THOMAS, J.L. 1989. Behavioral factors related to elderly alcohol abuse: research and policy issues. International Journal of the Addictions, 24(7):641-654.

HENDERSON, N. 2002. The resiliency route to authentic self-esteem and life success. Available: http://www.resiliency.com/htm/build.htm [Retrieved: 3 August 2003].

HILLMAN, J.L. 2000. Clinical perspectives on elderly sexuality. New York: Kluwer Academic /Plenum Publishers.

JANSON, M. \& KÖNIG, A. 2002. God, ek kan nie meer nie. Wellington: Lux Verbi.

JONES, R.E. 1997. Human productive biology ( $2^{\text {nd }}$ ed). San Diego, Calif: Academic Press.

JOUBERT, M. 2002. Die behoeftes van die alkoholis met verwysing na maatskaplikewerknasorgdienste. Potchefstroom: PU vir CHO. (Verhandeling - MA(MW))

JUNG, J. 1994. Under the influence: alcohol and human behavior. Pacific Grove, Calif.: Brooks/Cole.

KIRST-ASHMAN, K.K. 2003. Introduction to social work and social welfare: critical thinking perspectives. Pacific Grove, Calif.: Brooks/Cole-Thomson Learning.

KISTHARDT, W.E. 2002. The strengths perspective in interpersonal helping: purpose, principles and functions. In: SALEEBEY, D. (ed) The strengths perspective in social work practice $\left(3^{\text {rd }} \mathrm{ed}\right)$. Boston: Allyn and Bacon.

KLEINKE, C.L. 1998. Coping with life challenges $\left(2^{\text {nd }}\right.$ ed). Pacific Grove, Calif.: Brooks/Cole.

KRUGER, S.P. \& PIETERSE, L. 2004. Die benutting van musiek tydens groepwerk met dwelmafhanklikes. Maatskaplike Werk/Social Work, 40(4):399-411.

KÜBLER-ROSS, E. 2003. On death and dying. London: Tavistock/Routledge.

LEE, M. 1996. A constructivist approach to the help-seeking process of clients: a response to cultural diversity. Clinical Social Work Journal, 24(2):187-202.

LEE, M. 2003. A solution-focused approach to cross-cultural clinical social work practice: utilizing cultural strengths. Families in Society, 84(3):385-395. 
LOUW, D.A. 1993. Fisiologiese sielkunde. In: LOUW, D.A. \& EDWARDS, D.J.A., (reds) Sielkunde: 'n inleiding vir studente in Suider-Afrika ( $2^{\text {de }}$ uitg). Johannesburg: Heinemann. MASTERS, W.H., JOHNSON, V.E. \& KOLODNY, R.C. 1988. Masters and Johnson on sex and human loving. Boston: Little Brown.

McGINNIS, A.L. 1997. Balans in die lewe. Wellington: Lux Verbi.

MITCHELL, M. \& JOLLEY, J. 2001. Research design explained $\left(4^{\text {th }}\right.$ ed). Fort Worth: Harcourt College Publishers.

MONETTE, D.R., SULLIVAN, T.J. \& DEJONG, C.R. 2005. Applied social research: a tool for the human services $\left(6^{\text {th }} \mathrm{ed}\right)$. Belmont, C.A.: Brooks/Cole-Thomson Learning.

NASIONALE RAAD VIR GEESTESGESONDHEID. 1990. Lewensvaardighede vir selfontwikkeling. Johannesburg: Nasionale Raad vir Geestesgesondheid.

NICOL, J. 2000. Naak en naby: hersiene en bygewerkte uitgawe. Wellington: Lux Verbi.

NORMAN, E. 2000. Introduction: the strengths perspective and resiliency enhancement. In: NORMAN, E., (ed.) Resiliency enhancement: putting the strengths perspective into social work practice. Chichester, NY: Columbia University Press.

O'CONNELl, H., CHIN, A., CUNNINGHAM, C. \& LAWLOR, B. 2003. Alcohol use disorders in elderly people: redefining an age old problem in old age. BMJ, 327:664-667.

OSLIN, D.W. \& HOLDEN, R. 2002. Recognition and assessment of alcohol and drug dependence in the elderly. In: GURNACK, A.M., ATKINSON, R. \& OSGOOD, N.J., (eds) Treating alcohol and drug abuse in the elderly. New York, N.Y.: Springer Publication: 1131.

PARRY, C.D.H., PLUDDEMANN, A., STEYN, K., BRADSHAW, D., NORMAN, R. \& LAUBSCHER, R. 2005. Alcohol use in South Africa: findings from the first demographic and health survey (1998). Journal of Studies on Alcohol, 66(1):91-97. Available: Academic Search Premier. [Retrieved: 13 March 2007].

PERKINS, K. \& TICE, C. 1999. Family treatment of older adults who misuse alcohol: a strengths perspective. Journal of Gerontological Social Work, 31(3/4):169-185.

RAPP, C.A. 1998. The strengths model: case management with people suffering from severe and persistent mental illness. Oxford, NY: Oxford University Press.

ROUX, A.A. 2002. Evaluering van 'n groepwerk-hulpverleningsprogram met MIVpositief/VIGS-pasiënte. Potchefstroom: PU vir CHO. (Proefskrif - PhD)

RUBIN, A. \& BABBIE, E. 2005. Research methods for social work $\left(5^{\text {th }}\right.$ ed $)$. Belmont, CA: Brooks/Cole-Thomson Learning.

SALEEBEY, D. 2002. Introduction: power in the people. In: SALEEBEY, D. (ed.) The strengths perspective in social work practice $\left(3^{\text {rd }}\right.$ ed $)$. Boston: Allyn and Bacon.

SAS Institute Inc. The SAS System for Windows Release 9.1 TS Level 1MO Copyright (C) 2002-2005 by SAS Institute Inc., Cary, NC, USA.

SELEKMAN, M. 1991. The solution-oriented parenting group: a treatment alternative that works. Journal of Strategic and Systemic Therapies, 10(1):36-40. 
STALKER, C.A., LEVENE, E. \& COADY, N.F. 1999. Solution-focused brief therapy: one model fits all? Families in Society, 80(5):468-477.

STRYDOM, C. 1990. Die gebruikmaking van maatskaplike groepwerk in die uitbouing van die adolessente dogter se selfbeeld. Potchefstroom: PU vir CHO. (Verhandeling MA(MW))

STRYDOM, H. 2000. Maatskaplikewerk-navorsing (MWK 321/411). Potchefstroom: PU vir CHO. (Diktaat)

STRYDOM, H. 2005. Sampling and sampling methods. In: DE VOS, A.S. (ed) Research at grass roots $\left(3^{\text {rd }}\right.$ ed). Pretoria: Van Schaik.

THOMPSON, N. 2002. People skills $\left(2^{\text {nd }}\right.$ ed). New York: Palgrave.

TICEHURST, S. 1990. Alcohol and the elderly. Australian and New Zealand Journal of Psychiatry, 24:252-260.

TOSELAND, R.W. 1995. Group work with the elderly and family caregivers. Broadway, NY: Springer Publication.

TOSELAND, R.W. \& RIVAS, R.F. 2001. An introduction to group work practice $\left(4^{\text {th }}\right.$ ed). Boston: Allyn and Bacon.

VAKTAALKOMITEE VIR MAATSKAPLIKE WERK. 1984. Tweetalige definiërende woordeboek vir maatskaplike werk. Pretoria: Staatsdrukker.

VAN DYK, A. 2001. HIV/AIDS care and counselling: a multi-disciplinary approach. Cape Town: Pearson Education.

VAN JAARSVELD, P. 2003. Die hart van 'n wenner: ontwikkel jou emosionele intelligensie. Wellington: Lux Verbi.

VAN WORMER, K. \& DAVIS, D.R. 2003. Addiction treatment: a strengths perspective. Pacific Grove, Calif.: Brooks/Cole.

WALLER, M.A. 2001. Resilience in ecosystemic context: evolution of the concept. American Journal of Orthopsychiatry, 71(3):1-25. Available: Academic Search Premier.

WESSELS, C.C. 1996. Die doeltreffendheid van huweliksverryking: 'n verkennende maatskaplikewerk-ondersoek. Potchefstroom: PU vir CHO. (Verhandeling - MA(MW))

WIDNER, S. \& ZEICHNER, A. 1991. Alcohol abuse in the elderly: review of epidemiology research and treatment. Clinical Gerontologist, 11(1):3-18.

WITKEN, S.L. 1990. The implications of social constructionism for social work education. Journal of Teaching in Social Work, 4(2):37-48.

Dr. Stephan Geyer was 'n PhD-kandidaat in die Vakgroep Maatskaplike Werk, Skool vir Psigo-Sosiale Gedragswetenskappe, Noordwes-Universiteit, Potchefstroomkampus, tydens die ondersoek. Tans is hy verbonde aan die Departement Maatskaplike Werk \& Kriminologie, Universiteit van Pretoria, Pretoria; Prof. Herman Strydom het opgetree as promotor en is Vakhoof in die Vakgroep Maatskaplike Werk, Skool vir Psigo-Sosiale Gedragswetenskappe, Noordwes-Universiteit, Potchefstroomkampus, Suid-Afrika. 